\title{
Straf for frivillige seksuelle forhold - den store afkriminalisering
}

\author{
Morten Kjor, Adjunkt, Syddansk Universitet
}

\begin{abstract}
This article deals with the decriminalization of consensual sexual relations in Denmark 1683-1930. After the promulgation of Danske Lov 1683 the sexual offenses slowly disappeared from criminal legislation. Whereas the arguments in favor of criminalization had been the invocation of God's wrath, references to the Bible and public outrage, these arguments were abandoned in favor of more phlegmatic discussions of the positive and negative effects of criminalization. This ultimately led to the decriminalization of fornication, adultery, homosexuality and bestiality. Thus, today only fragments of the criminalization of the consensual sexual offenses exist in Danish criminal law. While criminal legislation often is remarkably conservative when it comes to the question of criminalization, the great decriminalization of the sexual offenses is an important example of discontinuity - on how the criminal law in Demark developed from 1683 to 1930.
\end{abstract}

\section{Introduktion: Strafferettens konservative natur}

Når det gælder spørgsmålet om forbrydelser, er strafferetten på mange måder et konservativt retsområde. I Danmark har handlinger som drab, voldtægt og tyveri været kriminaliserede i landskabslovenes straffebestemmelser i 1200-tallet, sjette bog i Danske Lov 1683, 1866-straffeloven og endelig 1930-straffeloven. Forfatning og religion er blevet forandret og reformeret, mens strafferetten har været anderledes immun. Med særlig henvisning til, at Danske Lovs sjette bog byggede på systematikken i de ti bud, fremhævede den danske retshistoriker Ole Fenger kontinuiteten i strafferetten og særligt betydningen af de ti bud i Bibelen:

»de [de ti bud] er i alt væsentligt grundlaget for den katolske kirkes ret - og for den nugældende danske straffelov.« (Fenger 2001, side 160).

Som kontrast til denne kontinuitet analyseres her afkriminaliseringen af de frivillige seksuelle forhold - sædelighedsforbrydelserne: Hvordan og med hvilke begrundelser blev sædelighedsforbrydelserne afkriminaliseret i perioden 16831930 ? 
Formålet med artiklen er at nuancere forståelsen af strafferettens udvikling ved at fremhæve et vigtigt eksempel på diskontinuitet. Samtidig er artiklen et eksempel på, hvordan afkriminalisering af forbrydelser kan blive realiseret og med hvilken argumentation. Endelig giver artiklen et indblik i den strafferetshistoriske kontekst for de nugældende straffebestemmelser.

Der anvendes en retshistorisk metode, hvor lovgivningen og dens forarbejder i forbindelse med Lejermålsforordningen 1812, der ophævede bøder for samleje mellem ugifte (lejermål), 1866-straffeloven og 1930-straffeloven analyseres for at undersøge, hvordan forbrydelsernes definition og straf udviklede sig og med hvilke begrundelser. Praksis vil blive inddraget med udgangspunkt i andre studier.

Sædelighedsforbrydelser bruges som betegnelse for de kriminaliserede frivillige seksuelle forhold og ligger i forlængelse af terminologien i retshistorisk forskning (f.eks. Jørgensen 2007, § 36 og Kjær 2017A). Begrebet har, som forbrydelserne, forandret sig gennem historien fra »Løsagtighed « i Danske Lov 1683, »Forbrydelser mod Sædeligheden« i 1866-straffeloven, »Forbrydelser mod Kønssædeligheden« i 1930-straffeloven til »Seksualforbrydelser« efter ændringen med lov nr. 633 af 12/06/2013. De sædelighedsforbrydelser, der undersøges, er lejermål, konkubinat (samliv mellem ugifte), hor (en ægtefælles samleje med en anden end ægtefællen) og i tilknytning hertil bigami, blodskam (samleje mellem beslægtede og besvogrede) og sodomi (homoseksualitet og bestialitet). Af de frivillige seksuelle forhold udelades kun prostitution, hvor forholdet til lejermål i Danske Lov alene kort berøres. Udeladelsen skyldes hensynet til artiklens længde, og prostitutions særlige karakter ift. lejermål (økonomisk aspekt og evt. organisering) herunder med særregler for rufferi. Mens prostitution er straffrit i dag, er rufferi strafbart jf. straffeloven, LBK nr. 1156 af 20/09/2018, § 233 (se Straffelovrådets Betænkning 2012 nr. 1534, kapitel 19).

Artiklen behandler først kriminaliseringen i Danske Lov 1683. Derefter analyseres ophævelsen af lejermålsbøder i 1812, 1866-straffeloven og 1930-straffeloven, hvorefter udviklingen i strafformål og argumentation diskuteres inden afslutningen.

\section{Udgangspunktet}

Før Reformationen var sædelighedsbrud noget, der primært lå under den katolske kirke og dens retssystem - kanonisk ret. Med Reformationen overtog staten jurisdiktionen fra kirken, og sædelighedsforbrydelserne blev optaget i den verdslige straffelovgivning kulminerende med Danske Lov i 1683, der derefter var ud- 
gangspunktet for sædelighedsforbrydelserne (se Kjær 2017A og Kjær 2017B, side 359-74).

Lejermål blev efter DL 6-13-1 straffet med bøder og åbenbart skrifte, der var et offentligt skriftemål i kirken, der blev opfattet som meget ydmygende. Efter praksis blev lejermål først anset for fuldbyrdet ved kvindens graviditet. Ved det tredje lejermål skulle kvinden kagstryges, dvs. piskes ved byens offentlige straffepæl - kagen, mens manden skulle straffes med fængsel. Hvis mandens lejermål var med kvinder, der ikke havde begået sædelighedsforbrydelser før, var straffen potentielt dødsstraf, jf. DL 6-13-8 og 9. DL 6-13-3 indeholdt i tilknytning til lejermål en uspecificeret trussel om straf for konkubinat. Mens lejermål principielt også omfattede prostitution, fastsatte DL 6-13-30 straf for kvinder, som bedrev prostitution på bordeller, og mænd, der blev pågrebet der. DL 6-22 om »Forlokkelse« indeholdt straf for »Ruffere og Ruffersker« for at lokke til usædelighed samt en særlig straf for at holde bordel.

For hor blev ægtefæller første gang straffet med en formuestraf - fortabelse af godset, anden gang yderligere med en forvisning fra landsdelen og tredje gang med døden, jf. DL 6-13-24. Hvis begge parter var gift (dobbelthor) og ikke stoppede forholdet efter advarsel, kunne dødsstraffen anvendes umiddelbart, jf. DL 613-25. I tilknytning til hor beskyttede reglen om bigami det monogame ægteskab og fastsatte dødsstraf, jf. DL 6-13-23.

For blodskam var det afgørende, om forholdet var imod »Guds Lov«. Hvis det var tilfældet, var straffen dødsstraf, jf. DL 6-13-14. »Guds Lov« må være en henvisning til 3 Mos. 18 og 20, men DL 6-13-14 udelod en selvstændig opremsning af de omfattede forhold. Udstrækningen af dødsstraffen var dermed usikker. Ud fra en subjektiv fortolkning måtte forbuddet være identisk med de opregnede forbud mod ægteskab i DL 3-16-9-1, 2 og 4, der byggede på en systematisk fortolkning af »Guds Lov«. Ordlyden af DL 6-13-14 muliggjorde derimod en efterfølgende indskrænkende fortolkning og dermed mildere straf i praksis (Holmboe 1961, side 144-45). Blodskam i 2., 2. + 3. og 3. led var reguleret i DL 6-13-13. Fætre og kusiner var beslægtet i 2 . led, grandfætre og grandkusiner i 3. led, mens et forhold mellem f.eks. en mand og hans fætters datter var et forhold i 2. + 3. led. Såanne forhold var ikke imod »Guds Lov« og blev i stedet straffet med forvisning og en bøde på personens formue samt ved gentagelse eller manglende overholdelse af forvisningen med dødsstraf.

Sodomi blev defineret som »Omgængelse, som er imod Naturen«, jf. DL 613-15. Med denne vage og generelle definition kunne befolkningen ikke opnå nærmere viden om de tabubelagte forhold, der var omfattet, mens den på den anden side var tilpas generel, så adskillige forhold kunne omfattes, herunder især 
homoseksualitet og bestialitet (von Rosen 1993, side 51-58, 78 og 397 og Holmboe 1961, side 143). Straffen var bålstraf, afbrænding af personen, men i praksis blev personen ofte kvalt, inden liget blev brændt (Holmboe 1961, side 143).

Reglerne i Danske Lov kodificerede tidligere lovgivning, der byggede på det generalpræventive formål og på ønsket om at undgå Guds fortørnelse, der ville resultere i en kollektiv afstraffelse af riget. Kriminaliseringen var nøje knyttet til religionen og ønsket om at sikre, at seksualitet kun kunne udfoldes inden for det monogame ægteskab mellem mand og kvinde. Sædelighedsforbrydelserne rubriceredes som overtrædelser af det sjette bud, og reglerne i Mosebøgerne, mosaisk ret, var inspiration for dødsstraffen for blodskam imod Guds lov og sandsynligvis også for sodomi. Endelig skulle kriminaliseringen bekæmpe forargelige handlinger. Efter gengældelsesteorier kan straf retfærdiggøres som gengældelse for forkerte handlinger, mens straf ifølge konsekvensteorier kan retfærdiggøres pga. dens gode konsekvenser (Viskum 2018, side 153). Kriminaliseringen af sædelighedsforbrydelserne byggede dermed på en kombination af disse argumenter. Straffen var retfærdig som gengældelse for seksuel synd og kunne i visse tilfælde være direkte angivet i mosaisk ret. Samtidig skulle straffens generalpræventive virkning beskytte ægteskabet, forhindre forargelse og ikke mindst Guds fortørnelse.

\section{1812: Ophævelsen af lejermålsbøder}

12. juni 1812 blev de almindelige bøder for lejermål ophævet (lovgivning 16701839 er trykt i Schous Forordninger). Bøden, der havde været en del af strafferetten siden middelalderen, og som efter Reformationen var blevet overført fra kirke til stat, forsvandt nu fra strafferetten. Ophævelsen og dens begrundelse var bemærkelsesværdig kortfattet. Efter en henvisning til forældrenes pligt til at bidrage til forsørgelsen af børn født uden for ægteskab, meddeltes det blot kort: »At Leiermaalsbøders Aftingelse [betaling] og Inddrivelse skal for Fremtiden være aldeles ophævet«.

Ophævelsen var kulminationen på et længere forløb med løbende diskussion af lejermålsforbrydelsen. En af enevældens centrale juridiske skikkelser, generalprokurør Henrik Stampe (1713-1789), der fungerede som regeringens juridiske rådgiver, måtte i 1761 tage stilling til forbrydelsen, da han skulle afgive erklæring om muligheden for at skærpe straffen for lejermål (trykt hos Tamm og Kjær 2013, side 58-61). Stampes holdning var klar:

»Jeg kan aldeles ikke alderunderdanigst råde til, i nogen måde at skærpe den straf, som loven har fastsat for letfærdige kvindfolk der lade sig besvangre. ${ }^{1}$ 
Stampes argumentation var renset for gengældelsesteoretiske overvejelser og frygt for Guds fortørnelse. I stedet fokuserede han på virkningerne af straffen og fastslog, at lejermålsbøderne havde haft »langt flere, eller i det mindste langt kendeligere onde end gode virkninger«. Særligt gjorde bøden det næsten umuligt at forsørge barnet for fattige kvinder. Pengemangel, skam og forholdets sociale konsekvenser kunne få fatale følger, og Stampe fremhævede risikoen for, at kvinden valgte at dræbe barnet og siden selv blev henrettet. Det var en henvisning til de i samtiden udbredte hemmelige fødsler og barnemord (se Nielsen 1999 og Krogh 2000, side 217-221). Ligeledes fungerede det åbenbare skrifte ikke efter hensigten. Mens det teologisk var tænkt som en forsoning med menigheden, havde det udviklet sig til en frygtet straf - især for kvinden. Selvom Stampe klart afviste strafskærpelse og fremhævede straffens ulemper, var hans konklusion forsigtig. I modsætning til værre sædelighedsforbrydelser som hor og blodskam, som efter hans mening naturligvis skulle straffes, var lejermål »et af de vanskeligste objekter, som de borgerlige love have med at bestille«. En afkriminalisering var problematisk, da det kunne hindre ægteskaber, og selvom Stampe var tilhænger af strafnedsættelse, var det »atter hel vanskeligt « at finde den passende straf. Mens Stampes tanker således vidner om et nyt syn på lejermål, blev der ikke gennemført større ændringer i denne omgang. Stampe nøjedes med at afvise forslaget om strafskærpelse med en tilføjelse om, at den eksisterende lovgivning snarere skulle mildnes end skærpes.

Stampe fik imidlertid rig mulighed for at beskæftige sig mere med forbrydelsen i de efterfølgende år. Forordning 14. oktober 1763 indførte underholdsbidrag for fædre til uægte børn og adresserede dermed en af de problemstillinger, som Stampe havde påpeget i 1761. Forordningen byggede på en erklæring fra Stampe efter forslag fra en biskop, der anså det som et bidrag til at begrænse usædelighed og drab på spædbørn (Koefoed 2008, side 229-30). Stampe fremhævede, at forslaget byggede på naturretten, og underholdspligten burde anses som »nyttig, billig og retfærdig« (trykt hos Tamm og Kjær 2013, side 65-67). Fire år senere blev Stampe ophavsmanden til afskaffelsen af det åbenbare skriftemål med Forordning 8. juni 1767. I sit udkast til Forordningen fremhævede han igen, at åbenbart skrifte fungerede imod hensigten, og at det medførte adskillige ulemper og forargelse. I modsætning til Stampes forslag erstattede den endelige forordning det åbenbare skrifte med 8 dages fængsel på vand og brød, som man mod en afgift kunne fritages for. Det tilgodeså tidligere praksis, hvor der blev dispenseret mod en afgift til Kancelliet, som dets embedsmænd fik del i. Forordningen sikrede dermed embedsstandens fortsatte indtægter fra dispensationer. Stampe tilføjede derfor i en 
note til udgivelsen af sit udkast, at han ikke var tilhænger af denne ændring (Tamm og Kjær 2013, side 69).

Med indførelsen af underholdspligt og afskaffelsen af åbenbart skrifte var de første store skridt taget mod en ophævelse af de almindelige lejermålsbøder. Hvad der skete herefter, er en påmindelse om rettens tilknytning til politikken, og hvor svært det kan være at tilpasse strafferetten til samfundsudviklingen i et tempo, der hverken er for hurtigt eller for langsomt. Den 6. maj 1771 befalede kongen Stampe at udfærdige en forordning om at afkriminalisere lejermål. I realiteten udgik ordren fra J. F. Struensee (1737-1772) og var et led i det omfattende reformprogram, der blev sat i værk i perioden 1770-72, inden han blev drevet fra magten og ultimativt henrettet. Stampe udfærdigede hurtigt et udkast til Forordningen, der udstedtes 13. juni 1771 med en begrundelse, der i høj grad mindede om Stampes overvejelser i 1761 (Tamm og Kjær 2013, s. 88-89 og Koefoed 2008, side 263-64):

»Gr. [grundet/pga.] Ved Bøderne og Straffen ere Forældrene ofte hindrede fra de dem paaliggende Pligter til Børnenes Opdragelse $\ll$.

Forordningen overlevede ikke Struensees fald og blev ophævet med Forordning 27. februar 1772. Ifølge forordningen havde afkriminaliseringen medført »mange forargelser, samt Ærbarheds og gode Sæders Overtrædelser« og forhindret ægteskaber. Med denne begrundelse, der blot manglede en henvisning til Guds fortørnelse for at svare til tidligere tiders begrundelser for at straffe lejermål, var status quo genoprettet. Fortalen står næppe helt til troende. Som den senere generalprokurør Christian Colbiørnsen (1749-1814), der var kritisk over for kriminaliseringen af lejermål, påpegede, krævedes der graviditet før lejermålsforbrydelsen var fuldbyrdet, mens forordningen blev ophævet, før der var gået 9 måneder (Tamm m.fl. 2006, side 301). Der var dermed endnu ikke nye lejermålsforbrydelser, der med sikkerhed var nået at blive omfattet af afkriminaliseringen.

Forordningen satte ophævelsen af lejermålsbøderne på pause. 23. maj 1800 blev erstatningsstraffen for åbenbart skrifte, der skulle give penge i form af dispensationer, afskaffet $\mathrm{i}$ forbindelse med en række lignende ophævelser af krav om bevillinger. Det var en kodificering af praksis (Koefoed 2008, side 285). Endnu 12 år skulle der gå, før de almindelige lejermålsbøder blev ophævet.

Den korte og ubegrundede ophævelse af lejermålsbøderne i 1812 er en bemærkelsesværdig afslutning på forbrydelsens eksistens i strafferetten. Mens kriminaliseringen af lejermål tidligere havde været en selvfølge, var den for Stampe blevet et problem, hvor det primært var hensynet til ægteskaber, der talte for fort- 
sat kriminalisering. Hertil fremhævede Forordning 1772 også det forargelige. Forargelsen kunne imidlertid give bagslag. Ved at kriminalisere lejermål og give anledning til retssager og åbenbart skrifte, blev handlingen netop kendt og egnet til at forarge endnu flere, og hensynet til at undgå forargelsen var et af Stampes argumenter for at afskaffe det åbenbare skriftemål. Samtidig var strafferetten i løbet af 1700-tallet endegyldigt løsrevet fra mosaisk ret og frygten for Guds fortørnelse. Den teologiske rådgivning, der havde spillet en stor rolle i strafferetten i 1700-tallets første halvdel med hyppige henvisninger til mosaisk ret, var blevet afløst af rådgivning fra Det Juridiske Fakultet eller fra generalprokurører som Stampe og Colbiørnsen, der ikke anså mosaisk ret som bindende (Iuul 1951, side 289-90 og Krogh 2000, side 116-18 og 360-63). Når frygten for Guds fortørnelse var blevet forladt, mosaisk ret ikke længere var bindende, og det forargelige lige så godt kunne være et argument imod kriminalisering, blev forbrydelsens eksistens mere og mere en lidenskabsløs afvejning af dens konsekvenser (smh. Koefoed 2008, side 300). Ultimativt blev kriminaliseringen en overflødighed, og netop ved at være kortfattet og ubegrundet vidner ophævelsen af lejermålsbøderne i 1812 om de nye tider med en lidenskabsløs afkriminalisering af en forbrydelse, der tidligere var blevet diskuteret og begrundet så lidenskabeligt.

\section{1866-straffeloven: Strafnedsættelsen}

I 1866 blev sjette bog i Danske Lov afløst af en ny straffelov, der kunne tage højde for de mange ændringslove, den ofte mildere praksis og afklare, hvordan strafferetten skulle udformes i det konstitutionelle Danmark (Iuul 1952, side 42-47). Landstingets betænkning over lovforslaget fra 1865 rettede derfor en principiel kritik af kriminaliseringen af sædelighedsforbrydelserne i Danske Lov:

»De hvile imidlertid i en Anskuelse om Handlingernes Strafbarhed, som Nutiden ikke kan vedkjende sig, de bedømmes efter Datidens religieuse Standpunkt snarere som Forbrydelser mod Moralen og »Guds Lov«, end som Brud på Retsordenen, som Gjerninger, der enten umiddelbart indeholde Krænkelse af Andres Ret eller støde an imod den almindelige Sædelighedsfølelse og vække offentlige Forargelse, og de belægges dermed med de strengeste Straffe.« (Landstingets betænkning side 48, 1. spalte).

1866-straffeloven indeholdt derfor flere ændringer. Den største ændring var strafnedsættelserne, og alle dødsstraffe blev afskaffet. Til gengæld var konkubinat, hor, bigami, blodskam og sodomi fortsat kriminaliseret, jf. §§ 159-165 og 177-78. Samtidig var strafnedsættelsen i høj grad en kodificering af praksis (Holmboe 1961, side 128-55). Lovgiver havde således med loven »bestræbt sig for at lade 
den allerede nu virkelig gjældende Ret træde frem i egentlig Lovsform« (Landstingets betænkning, side 49, 1 . spalte).

Den eneste direkte afkriminalisering var ophævelsen af gentagelsesstraffen for lejermål. Mens kagstraffen var afskaffet med Forordning 19. marts 1751, blev gentagelsesstraffen først nu afskaffet. I det første udkast til 1866-straffeloven fra 1859 skulle der efter $\S 78$ fortsat straffes i form af fængsel for at begå lejermål med tre forskellige personer (Foreløbigt Udkast, motiver til $\S 78$, side 28). Mens en enkelt person i kommissionen havde foreslået afkriminalisering, argumenterede flertallet med nødvendigheden af at straffe åbenlys, grov usædelighed. Det synspunkt blev forladt i udkastet fra 1864. Mens kommissionen medgav, at gentagne lejermål var grov og åbenlys usædelighed, henviste de til det ulogiske $\mathrm{i}$ at have en gentagelsesstraf, når det første lejermål var straffrit, at »Løsagtighed « også kunne have andre former, og at straffen ville blive vilkårlig, da den forudsatte graviditet (Udkast til Straffelovbog, motiver side 211-12).

Konkubinat blev under tvivl opretholdt som en forbrydelse i § 178 »af Hensyn til den almindelige Sædelighedsfølelse og Agtelse for Ægteskabets Hellighed«. Straffen var fængsel, og som før krævede det en forudgående advarsel. Som en yderligere begrænsning skulle det være op til domstolene, om det forsatte samliv udgjorde det »qvalificerede, forargelige samliv«, der udgjorde gerningsindholdet (ibid. side 210-11).

For hor blev den selvstændige kriminalisering af dobbelthor afskaffet, så det alene kunne få betydning ved udnyttelsen af strafferammen for forbrydelsen. Samtidig fremgik det klart af forarbejderne, at den ugifte part ikke skulle straffes, da dette dels var en fortsættelse af gældende ret, og da hor blev betragtet som en ægtefælles brud på sit eget ægteskab (ibid. side 188-89). Begge dele stod i kontrast til den mere konservative linje i udkastet fra 1859 (Foreløbigt Udkast $\S \S 61$ 62). Efter $\S 159$ skulle hor straffes med fængsel eller under særligt formildende omstændigheder med bøde. Det lå i forlængelse af benådningspraksis (Iuul 1952, side 23 og Holmboe 1961, side 138). Den væsentligste ændring for hor lå i påtalereglerne. Mens påtalen tidligere havde været offentlig, skulle der nu kun rejses påtale, hvis »den fornærmede Ægtefælle forlanger det«, jf. $\S 159$, 2. pkt. I et vist omfang var det i forlængelse af en regel fra 1824 om, at der som hovedregel kunne benådes for hor, når den krænkede ægtefælle anmodede om det (Holmboe 1961, side 136). På denne måde løste 1866-straffeloven en klassisk diskussion om, hvorvidt hor var et offentligt eller privat anliggende. I de middelalderlige kirkelove for Sjælland og Skåne samt i Skånske Lov og Eriks sjællandske Lov var det blevet indskærpet, at det var forbeholdt ægtemanden at rejse sag for hor mod hustruen. Dette krav stod i modstrid med den katolske kirkes ønske om at 
betragte hor som et offentligt anliggende under kirkens jurisdiktion og vidner dermed om en kamp om jurisdiktion over en forbrydelse (Kjær 2017B, side 86 og Korpiola 2014). Med statens overtagelse af jurisdiktion fra kirken efter Reformationen vandt den kirkelige opfattelse af hor som en offentlig forbrydelse. Danske Lov fastsatte offentlig påtale, mens Struensee som led i forsøget på afkriminalisering af lejermål fik tilføjet en bestemmelse til Stampes udkast om, at hor kun skulle straffes, hvis den krænkede ægtefælle begærede det. Det ville have gjort hor til et privat anliggende som et klart brud på hidtidig praksis (Tamm og Kjær 2013, side 89 og Koefoed 2008, side 264). Spørgsmålet blev igen taget op af Colbiørnsen i straffelovskommissionen i 1800 (Tamm m.fl. 2006, side 301-2). Han betragtede hor som en privat forbrydelse og henviste til, at den uskyldige ægtefælle indirekte blev ramt af formuestraffen, og at det var krænkende, at en sag blev gennemtvunget for en mand, der ønskede at undgå offentlig »beskæmmelse« og tilgive sin hustru. Med 1866-straffeloven blev hor nu en privat forbrydelse. Det er et endegyldigt vidnesbyrd om, at nødvendigheden af offentlig straf for hor for at afbøde Guds fortørnelse, var aflivet for denne forbrydelse (smh. Koefoed 2008, side 265).

Bigami skulle straffes med strafarbejde fra to til seks år, eller under særligt formildende omstændigheder med forbedringshusarbejde eller fængsel på vand og brød i mindst 20 dage, jf. $§ 160$. Som noget nyt blev det direkte fastsat, at også den ugifte part skulle straffes, dog med en mildere straf. Mens straffen for den ugifte part tidligere blev betragtet som hor (Kjær 2017B, side 180), blev forholdet nu udtrykkeligt en del af bigamiforbrydelsen. Ifølge motiverne burde den ugifte part straffes, fordi »der væsentlig bidrages til, at en saa grov Forbrydelse som Bigami bliver begaaet.« (Udkast til Straffelovbog, side 192).

Blodskam blev behandlet i $\S \S 161-165$, der i modsætning til DL 6-13-14 definerede samtlige forhold udførligt. Blodskam omfattede forhold mellem slægtninge i op- og nedstigende linje og mellem søskende, jf. $\S \S 161$ og 164. Dertil var forhold med stedbarn eller dets afkom, eller svigerbørn eller i nedstigende linje beslægtede svigerbørn, samt forhold til stedforældre eller ægtefælles slægtninge i opstigende linje strafbare efter $\S 162$. Som tidligere blev svogerskab ikke alene stiftet ved ægteskab men også ved samleje, jf. § 163. Endelig blev det almindelige forhold mellem ægteskabsreglerne og straf for blodskam opretholdt, da samtlige forhold mellem beslægtede og besvogrede, som ikke kunne giftes uden bevilling, var strafbare, jf. $§ 165$. Op til 1866-straffeloven var blodskamsforbuddet udhulet ved dispensationer til ægteskab, og for de fjerneste forhold var kravet om dispensation til indgåelse af ægteskab helt bortfaldet (Holmboe 1961, side 15154). 
Straffen for blodskam blev bragt i overensstemmelse med benådningspraksis (ibid. side 144-55), og den maksimale straf var for en persons forhold med slægtningene i nedstigende linje, hvor straffen var strafarbejde fra 4 indtil 10 år. For personer i nedstigende linje åbnede straffeloven nu op for mildere straffe. Begge ændringer var tilsigtede og blev rost af Landstingets udvalg (Landstingets betænkning, side 49, 2. spalte, smh. Udkast til en Straffelovbog, side 195-98).

Sodomi blev fortsat defineret som »Omgængelse mod Naturen« i § 177 og skulle straffes med forbedringshusarbejde. Helt op til 1866 havde Højesteret dømt efter ordlyden i DL 6-13-15 men med henstilling om formildelse af straffen, der efter praksis svarede til den, der nu og helt tilsigtet blev en del af lovgivningen (Holmboe 1961, side 144 og Udkast til en Straffelovbog, side 210). Det var også tilsigtet, at definitionen videreførtes uændret:

»Ved Affattelsen af Udkastets $§ 174$ har man ikke anset det nødvendigt [...] nærmere at betegne de forskjellige Maader (med Personer af det samme eller af det andet Kjøn eller med Dyr), hvorpaa den unaturlige Vellyst kan finde Sted« (Udkast til en Straffelovbog, side 210).

Dyrets skæbne blev betragtet som et administrativt spørgsmål. Det var ikke behandlet i Danske Lov, men inspireret af mosaisk ret havde Højesteret ofte dømt dyret til at brændes (Holmboe 1961, side 142-44).

1866-straffeloven medførte således en klar justering af straffen i overensstemmelse med den eksisterende benådningspraksis. Mens dette for så vidt var en udramatisk justering, gjorde forarbejderne det i klare vendinger klart, at synet på sædelighedsforbrydelserne var et andet i 1866 end i 1683. Landstingets udvalg lagde endegyldigt opfattelsen af sædelighedsforbrydelser som overtrædelse af Guds bud i graven, og på tilsvarende vis lagde de to første udkast til loven afstand til straffeideologien bag Danske Lov. 1866-straffeloven fortsatte imidlertid den vidtgående kriminalisering af trusler mod det heteroseksuelle, monogame ægteskab: konkubinat, hor, bigami og sodomi, mens blodskam mere kan anskues som et værn om det til ægteskabet knyttede familieliv. Der var således stadig tale om en klar og tydelig arv fra tidligere tiders opfattelse af sædelighedsforbrydelserne. De store forandringer lå i løsrivelsen fra den direkte afhængighed af mosaisk ret og mere generelt i frygten for Guds fortørnelse. Det var dermed ikke uden grund, at de nye tider for sædelighedsforbrydelserne blev fremhævet i forarbejderne, hvor det kunne fastslås, at: 
»Anskuelserne neppe om nogen anden Forbrydelses strafbarhed ere blevne saa meget paavirkede og forandrede af Tidsaanden som netop disse. " (Foreløbigt Udkast, motiver til kap. 8, side 21, smh. Udkast til en Straffelovbog, side 187 og Landstingets betænkning, side 48, 1. spalte).

\section{1930-straffeloven: Afkriminaliseringen}

For sædelighedsforbrydelserne blev 1930-straffeloven det store lovgivningsmæssige vendepunkt. Hor, homoseksualitet og bestialitet blev afkriminaliseret, mens konkubinat kun undtagelsesvist skulle straffes. Kun bigami og blodskam var fortsat strafbart. Som ved 1866-straffeloven anslog det første forarbejde også her en mere forsigtig tone. I betænkningen fra 1912, der var den første af de tre betænkninger, som straffeloven byggede på, blev der argumenteret for at beholde straffen for hor og i mindre omfang konkubinat. For kommissionen var kriminaliseringen af begge forhold en konsekvens af ægteskabets status (Betænkning 1912, motiver side 210 og 216). Samtidig foreslog kommissionen klare begrænsninger i mulighederne for at straffe forbrydelserne. For konkubinat skulle i modsætning til 1866-straffelovens $\S 178$ alene de offentlige og forargelige forhold straffes. $§ 217$ straffede således med arbejdsfængsel eller ved formildende forhold simpelt fængsel den:

»der stiller kønslig usædelig Levevis til Skue eller opfordrer eller indbyder til Utugt paa en Maade, hvorved nogen forulempes, eller som er egnet til at vække almen Forargelse.«

Motiverne indskærpede derfor, at et konkubinat, der blev ført »uden at Omverdenen udfordres«, var straffrit (Betænkning 1912, motiver side 210).

For hor skulle straffen efter $\S 227$ være fængsel indtil tre måneder. Som en bemærkelsesværdig udvidelse ift. 1866-straffeloven omfattede bestemmelsen også »ugift, der har Samleje med nogen gift«. Påtale krævede begæring fra »en fornærmet Ægtefælle« med de yderligere krav, at ægteskabet var opløst eller blev begæret opløst i forbindelse med straffesagen, og at begæringen blev fremsat senest tre måneder efter ægtefællens kendskab til forholdet. Udover hensynet til ægteskabets status henvistes til udenlandske straffelove, der heller ikke havde afkriminaliseret forbrydelsen. De skærpede påtalekrav blev begrundet med hensynet til »det bestaaende Ægteskabs Fred«. Den voksende skepsis mod forbrydelsen illustreres af et mindretal, der argumenterede for afkriminalisering, da »Straffeloven ikke har til Opgave at drage Grænsen mellem det moralske og det umoralske.« (Betænkning 1912, motiver side 216).

Carl Torp (1855-1929), der afgav sin betænkning om det første udkast i 1917, betragtede hor og konkubinat $\mathrm{i}$ et andet lys. Straffen for konkubinat var »ganske 
forfejlet«, og »den almindelige Retsopfattelse« krævede afkriminalisering af straffen, der var

»en Reminiscens af gammelkirkelig Straffejustits mod den, der krænker Kirkens Fordring om Ægteskab som eneste tilladelige Kønsforbindelse.«(Betænkning 1917, motiver side 197-98).

Efter Torps opfattelse var straffen for konkubinat en klasselov og førte til »Indblanding i Folks private Liv og Moralopfattelse« samt skabte angiveri. Samtidig var henvisningen til ægteskabets status paradoksal, da denne argumentation også måtte medføre en genkriminalisering af lejermål. Bestemmelsen skulle derfor ændres, så den alene omfattede prostitution (ibid.).

Lige så kritisk stillede Torp sig til forslaget om at bevare straffen for hor (ibid. side 180-81). Med henvisning til påtalebegrænsningerne og eksisterende praksis fremhævede han, at »af 100.000 Ægteskabsbrud straffedes næppe et«. Med de foreslåede yderligere påtalebegrænsninger ville hor kun straffes, hvor ægteskabet var »undermineret«, hvorfor forseelsen var undskyldelig, og en ægtefælles begæring om påtale ofte ville være hævn eller afpresning. Samtidig ville straffen særligt ramme kvinden, da det pga. graviditet nemmere ville kunne bevises, mens det efter Torps mening oftere var manden, der begik hor. For Torp kunne de almindelige ægteskabsregler give passende beskyttelse i tilfælde af hor, navnlig retten til skilsmisse. Også kommissionens henvisning til udenlandsk lovgivning blev afvist:

»Ogsaa andre Straffebestemmelser - f. Eks. mod Kætteri, Trolddom, simpelt Lejermaal, crimen bestialitatis - har i kraft af Traditionens Magt i Lovgivningerne været opretholdte adskillig Tid, efter at de i den almindelige Bevidsthed var dødsdømte.« (ibid. side 181).

Det var alle forbrydelser, der havde ligget under den katolske kirkes jurisdiktion, og som med Reformationen var blevet overtaget af staten og endegyldigt defineret i Danske Lov 1683. I tiden derefter blev forbrydelserne langsomt afkriminaliseret, og med 1930-straffeloven var tiden nu kommet til mange af de resterende sædelighedsforbrydelser (Kjær 2018).

Torps argumentation vandt genklang i den sidste betænkning fra 1923. Til forskel fra Torps udførlige og næsten lidenskabelige argumentation, var argumentationen nu kort og tør. For hor blev afvisningen af en fortsat kriminalisering klaret på tre korte afsnit. Kommissionen konstaterede som Torp, at straffen for hor primært ville aktualiseres, når ægteskabet var brudt sammen, og at der ofte ville være motiver »af lidet tiltalende Art« hos den ægtefælle, der begærede påtale. Da straffen »næppe kan anses for et egnet Middel til at værne om Ægteskabets Ren- 
hed «, burde bestemmelsen udgå (Betænkning 1923, motiver side 307). Konkubinat blev afvist med et kort afsnit, hvor der med henvisning til den sjældne brug af 1866-straffelovens $§ 178$ konkluderedes:

»Den almindelige Retsfølelse vil sikkert nu ikke finde det naturligt, at Konkubinat som saadant straffes« (ibid. side 330-331).

Lovgiver ville det imidlertid anderledes og fulgte den første betænkning med 1930 -straffelovens $\S 233$. Bestemmelsen fik imidlertid stort set ingen praktisk betydning og er senere ændret, så den ikke længere kan ramme ugifte samlevende (Straffelovrådets betænkning 2012 nr. 1534, side 483-99).

Mens konkubinat og hor havde været genstand for diskussion, var der enighed om afkriminaliseringen af homoseksualitet og bestialitet i henhold til argumentationen i den første betænkning (Betænkning 1917, motiver side 194 og Betænkning 1923, motiver side 323-24). Den første kommission foreslog i § 213 en særlig straf for personer over 25 år, der »øver kønslig Usædelighed« med personer af samme køn under 21 år, og for homoseksuel prostitution for både kunden og den prostituerede (Betænkning 1912, motiver side 206, smh. 1930-straffeloven $\S \S$ 225, stk. 2 og 230). Derimod blev der ikke foreslået en almindelig straf for homoseksualitet:

»At udvide Strafbarheden udover dette Omraade vilde sikkert modarbejde i Stedet for at fremme Almensædeligheden. Gjorde man i al Almindelighed Forholdet strafbart, vilde man give Justitien umulige Opgaver at gennemføre og kun bidrage til, at Forhold, der, foretagne i Stilhed mellem voksne og ansvarlige Personer, ingen skadelig Indflydelse have paa Almenheden, ville blive dragne frem for Offentligheden og netop derigennem udbrede moralsk Smitte.« (Betænkning 1912, motiver side 206-7).

Begrundelsen for afkriminalisering af homoseksualitet står derfor i skarp kontrast til begrundelserne ved konkubinat og hor. Et er at afkriminalisere forhold, fordi de hører privatlivet til, straffen strider mod retsfølelsen eller ud fra tørre konsekvensteoretiske betragtninger. Noget andet er at argumentere for afkriminaliseringen af en handling, som er egnet til »moralsk Smitte«. På sin vis er argumentationen den ultimative konsekvens af det ambivalente forhold til omgængelse mod naturen gennem strafferetshistorien. Mens den på den ene side var en religiøs legitimeret forbrydelse, var den samtidig så forargelig, at den absolut ikke skulle defineres præcist. Da den religiøse begrundelse blev forladt, blev forbrydelsen afkriminaliseret af hensyn til forargelsen. Mens Torp kunne argumentere for, at konkubinat var privat og derfor ikke burde straffes, hvilede afkriminaliseringen af 
homoseksualitet på ønsket om, at homoseksualitet skulle vaere privat og derfor ikke måtte straffes. Dermed bliver afkriminaliseringen af homoseksualitet et forsøg på at begrænse dens udbredelse i samfundet. Som det sidste præventive tiltag mod forbrydelsen blev den afkriminaliseret.

Behandlingen af bestialitet var kortfattet. Efter kommissionens opfattelse var det »udenfor Retsordenens Opgave« at straffe bestialitet i almindelighed, og da straffen sjældent blev brugt, ville den ikke blive savnet. Der var ingen overvejelser om dyrehensyn, og handlingen blev sammenlignet med onani, »Selvbesmittelse«, der heller ikke blev straffet. Bestialitet kunne imidlertid fortsat straffes efter andre bestemmelser, hvis det krænkede blufærdigheden eller vakte offentlig forargelse (Betænkning 1912, motiver side 207, smh. 1930-straffeloven $\S \S 232-33$ ).

For bigami var straffen efter $\S 208$, stk. 1, fængsel indtil 3 år for den gifte person, og hvis den anden person var uvidende om det bestående ægteskab, steg straffen op til 6 år. Den ugifte person blev straffet med fængsel eller hæfte indtil 1 år, jf. stk. 3. Hvis det bestående ægteskab ikke kunne omstødes, kunne straffen for den gifte halveres samt bortfalde for den ugifte, jf. stk. 4. Den højere straf, hvis den seneste ægtefælle var uvidende om forholdet, blev begrundet som en »høj strafværdig Krænkelse« af den godtroende part, mens den almindelige straf for bigami skyldtes »Samfundets Interesse i Beskyttelsen af Ægteskabsinstitutionen« (Betænkning 1923, motiver side 308). En tilsvarende argumentation var omvendt forladt for hor.

Blodskam var fortsat strafbart for forhold mellem slægtninge i direkte op- og nedstigende linjer og mellem søskende, jf. § 210, stk. 1. Personer, der havde samleje med slægtninge i den opstigende linje, blev kun straffet, hvis de var over 18 år, jf. stk. 2. Dertil var det strafbart at indgå et ægteskab, der kunne omstødes pga. blodskam, ligesom samleje mellem besvogrede var strafbart, når ægteskab mellem dem var ubetinget forbudt, jf. $\S 209$ og 211. Efter $\S 212$ skulle forholdet straffes forholdsmæssigt mildere ved anden kønslig omgængelse end samleje. Straffelovens bestemmelser flugtede med det indskrænkede blodskamsforbud i den nye ægteskabslov fra 1922, jf. lov nr. 276 af 30/6 1922 §§ 12-14, 42 og 84.

Betænkning 1923 er stort set renset for en argumentation for strafbarheden af blodskam og fokuserede primært på strafforskellen på forældre og børn. I forlængelse af straffen for anden kønslig omgængelse end samleje fremhæves »Besmittelse af Familielivets Renhed « i en bisætning (Betænkning 1923, motiver side 310). Den første kommission fremhævede kort nødvendigheden af strafnedsættelser og indskrænkning af blodskamsforbuddet. Straffen i direkte op- og nedstigende forhold og mellem søskende fulgte af »den almene Følelse«, der krævede »Afholdenhed«. Mens en fortsat kriminalisering af forhold mellem besvogrede i 
direkte op- og nedstigende linje skulle hindre en svækkelse af forholdets »moralske Betydning « (Betænkning 1912, motiver side 220). Den mest udførlige drøftelse findes hos Torp. Mens han forgæves foreslog straffrihed for forhold mellem besvogrede og anså straffen som udtryk for »forældede kirkelige Bud « (Betænkning 1917, motiver side 184), drøftede han udførligt begrundelsen for at straffe forhold mellem beslægtede. Mens Torp afviste faren for arvelige sygdomme hos børnene som strafgrund, var den ultimative begrundelse den samfundsmæssige interesse i at sikre »Familiens Samliv«:

»En virkelig Garanti for disse Familieforholds Renhed opnaas imidlertid netop kun, naar Uviljen imod, ja man kan sige Rædslen for Kønsforbindelser mellem disse nærbeslægtede bevarer den nedarvede instinktmæssige Karakter, som den har, og følgelig betragtes som et kategorisk og ufravigeligt Imperativ.« (ibid. side 183).

Mens kun en rest af konkubinat fortsat og alene teoretisk kunne straffes, stod blodskam og bigami tilbage i straffeloven som nødvendige forbrydelser for at værne om henholdsvis familielivet og det monogame ægteskab. Blodskam og bigami blev derfor ikke optaget i kapitlet om »Forbrydelser mod Kønssædeligheden« men i det nye kapitel om »Forbrydelser i Familieforhold«.

\section{Argumentation, strafformål og afkriminalisering}

Argumentationen for afkriminaliseringen af sædelighedsforbrydelserne illustrerer et vigtigt skifte i synet på strafferetten og dens formål. Mens kriminaliseringen af sædelighedsforbrydelserne var legitimeret ud fra både gengældelsesteoretiske og konsekvensteoretiske argumenter, stod afkriminaliseringen i konsekvensteoriens tegn. Det var muliggjort med et nyt syn på strafferetten som vandt frem i 1700tallet, hvor strafferetten kunne løsrives fra bindingen til mosaisk ret og idéer om gengældelse til alene at fokusere på dens konsekvenser. Fra at være en selvfølge kunne kriminaliseringen ud fra konsekvensbetragtninger blive et problem og ultimativt overflødig. Mens tanker om straffens virkning på ingen måde var nyt, og det generalpræventive formål havde været en del af strafferetten siden middelalderen, var denne brug af konsekvensbetragtninger ny. Her blev selve strafbarheden af et forhold vurderet ud fra straffens konsekvenser, og det ledte til afkriminalisering. Samtidig blev den generalpræventive virkning i højere grad betragtet med skepsis. Straf blev således ikke fundet egnet til at beskytte mod hor og var decideret kontraproduktiv ift. homoseksualitet.

Mens kriminaliseringen af de seksuelle lidenskaber havde været præget af en næsten tilsvarende lidenskabelig straffeideologi begrundet i forargelsen og fryg- 
ten for Guds fortørnelse, fremstår afkriminaliseringen derimod underligt lidenskabsløs. Lejermål blev afkriminaliseret næsten uden begrundelse efter drøftelser af fordele og ulemper ved straffen, mens hor ultimativt faldt på en konsekvensteoretisk betragtning. Bestialitet forsvandt med en kort henvisning til dens sjældne brug, og at onani ikke straffedes. Den lidenskabsløse afkriminalisering er måske i sig selv et vidnesbyrd om, at det var muligt at afkriminalisere sædelighedsforbrydelserne. Så snart en lidenskabsløs diskussion af fordele og ulemper var mulig, var afkriminalisering en reel mulighed. Den eneste af de afkriminaliserede forbrydelser, der blev omtalt mere lidenskabeligt, var den klare fordømmelse af homoseksualitet. Det blev imidlertid et argument for afkriminalisering for at beskytte offentligheden for unødig viden om sådanne handlinger.

Afkriminaliseringen byggede på idéen om, at moral og strafferet ikke altid skal være identiske. Sædelighedsforbrydelserne blev ikke afkriminaliseret, fordi de blev anset for moralske. De blev afkriminaliseret ud fra konsekvensbetragtninger, der byggede på idéen om, at ikke alt, der var umoralsk, skulle straffes. Ligesom en religiøs begrundelse for kriminaliseringen var blevet forladt, blev en mere generel moralsk begrundelse det i vidt omfang med 1930-straffeloven. Det kom til udtryk hos mindretallet i den første betænkning, der afviste kriminaliseringen af hor, da strafferetten ikke skulle drage grænsen mellem det moralske og det umoralske, mens afkriminaliseringen af homoseksualitet blev legitimeret som en begrænsning af handlingen. Brugen af konsekvensteoretiske argumenter muliggjorde dermed en argumentation for afkriminalisering af forhold, som fortsat kunne betragtes som umoralske. Dermed blev strafferetten nemmere at forandre, og for sædelighedsforbrydelserne behøvede afkriminaliseringen ikke at gå hånd $\mathrm{i}$ hånd med ændringer i samfundsmoralen.

\section{Afslutning: Den store afkriminalisering}

Fra Danske Lov til 1930-straffeloven skete der store forandringer for sædelighedsforbrydelserne. Straffeideologien, straffene og forbrydelserne undergik alle forandringer, og resultatet er et vidnesbyrd om strafferettens udvikling. Frygten for Guds fortørnelse blev forladt, ligesom regler i mosaisk ret ikke længere blev anset for bindende. Straffen blev mildnet, og dødsstraffen forsvandt i praksis for sædelighedsforbrydelserne og ultimativt lovgivningsmæssigt med 1866-straffeloven. Lejermål, hor, homoseksualitet og sodomi blev afkriminaliseret, mens konkubinat kun teoretisk fortsat kunne straffes. Som forbrydelser bestod efter 1930-straffeloven fortsat kun bigami og et meget begrænset blodskamsforbud. 1930-straffeloven markerede naturligvis ikke afslutningen på diskussionerne om kriminalisering, som er fortsat til i dag (se Kjær 2017A, side 72-73, Greve 2008 
og Straffelovrådets betænkning 2012 nr. 1534). Mens straffen for blodskam er yderligere indskrænket, så den kun gælder for forhold i nedstigende linje og mellem søskende, bygger bigami fortsat på de samme principper, jf. straffeloven $\S \S$ 208 og 210. Bestialitet blev genkriminaliseret i 2015 og er omfattet af dyreværnslovens, LBK nr. 20 af 11/01/2018, § 3 a. Ingen af disse forbrydelser er i dag en del af straffelovens kapitel om seksualforbrydelser. Terminologiændringen til seksualforbrydelser skete i 2013 med en begrundelse, der er en konsekvens af den store afkriminalisering af frivillige seksuelle forhold:

»Der er tale om en sproglig modernisering, som samtidig understreger, at den beskyttelsesinteresse, som varetaget i bestemmelserne i straffelovens kapitel 24, er den enkeltes seksuelle selvbestemmelse og integritet.« (Straffelovrådets betænkning 2012 nr. 1534, side 29).

Den store afkriminalisering er et vidnesbyrd om strafferettens udvikling og et vigtigt eksempel på diskontinuitet. Udviklingen foregik gradvist over et kvart årtusinde, hvor praksis ofte gik forud for lovgivning. Den viser, hvordan kriminalisering af forhold, der tidligere var selvfølgelige, kan problematiseres ud fra konsekvensteorietiske betragtninger og ultimativt opgives. Som et studie i afkriminalisering vidner det om gennemslagskraften af konsekvensteoretiske argumenter fra Stampes overvejelser i 1700-tallet til 1930-straffelovens forarbejder, der med held argumenterede for afkriminalisering af hor, homoseksualitet og bestialitet. Det var muliggjort med opgivelsen af en religiøs strafferetsideologi, der havde dikteret straf for sædelighedsforbrydelserne. Afkriminaliseringen vidner også om en mindre optimistisk tilgang til straffelovgivning og straffens generalpræventive virkning. For de sædelighedsforbrydelser, der blev afkriminaliseret, var alle de mange generalpræventive foranstaltninger, som Danske Lov byggede på, mislykkedes. I det lange løb blev sædelighedsforbrydelserne ikke udryddet, de blev afkriminaliseret.

\section{Note}

1. Citater fra kilder er kun moderniseret, hvis de som her er det i de citerede kildeudgaver.

\section{Litteraturliste}

Betcenkning om Lovudkastet til Straffelov for Kongeriget Danmark, Landstingets Udvalg, København 1865 [Landstingets betænkning].

Betcenkning afgiven af Kommissionen nedsat til at foretage et Gennemsyn af den almindelige borgerlige Straffelovgivning, J.H. Schultz 1912 [Betænkning 1912].

Betcenkning afgiven af Straffelovskommissionen af 9. November 1917, J.H. Schultz 1923 [Betænkning 1923]. 
Betcenkning angaaende de af den under 11. August 1905 nedsatte Straffelovskommission udarbejdede Forslag indeholdende Udkast til Love vedrørende den borgerlige Straffelovgivning med Motiver, J. H. Schultz 1917 [Betænkning 1917].

Fenger, Ole (2001). Lov og ret i Europas historie. Aarhus: Aarhus Universitetsforlag.

Foreløbigt Udkast til Lov om Forbrydelser, J.H. Schultz 1859 [Foreløbigt Udkast].

Greve, Vagn (2008). Incest - Retspolitiske betragtninger. Tidsskrift for Kriminalret, TfK2008.453.

Iuul, Stig (1951). Den gamle danske strafferet og dens udvikling indtil slutningen af det 18. århundrede. I: Leif Beckmann og Herluf Petersen (red.), Kampen mod Forbrydelsen I, København: Emil Wienes Forlag, s. 239-94.

Iuul, Stig (1952). Den danske strafferets udvikling i tiden efter ca. 1800. I Leif Beckman og Herluf Petersen (red.): Kampen mod Forbrydelsen II, København: Emil Wienes Forlag, s. 11-52.

Jørgensen, Poul Johannes (2007). Dansk strafferet fra Reformationen til Danske Lov. København: Jurist- og Økonomforbundets Forlag.

Kjær, Morten (2017A). Straf for frivillige seksuelle forhold - en arv fra Reformationen? Nordisk Tidsskrift for Kriminalvidenskab, 2017, årgang 104 nr. 1, s. 60-76.

Kjær, Morten (2017B). Guds og øvrigheds straf - centralmagt og sædelighed i Danmark-Norge. København: Ex Tuto.

Kjær, Morten (2018). Reformation og straf. Ugeskrift for Retsvcesen, U.2018B, s. 21-23.

Koefoed, Nina Javette (2008). Besovede kvindfolk og ukærlige barnefædre. Køn, ret og sædelighed i 1700-tallets Danmark. København: Museum Tusculanums Forlag.

Korpiola, Mia (2014). "Only the Husband Can Acuse the Wife of Adultery and She Him«: Prosecuting and Proving Adultery in Medieval Sweden. Zeitschrift der Savigny-Stiftung für Rechtsgeschichte, 131 (2014), s. 223-61.

Krogh, Tyge (2000). Oplysningstidens og det magiske. Henrettelser og korporlige straffe i 1700tallets første halvdel. København: Samleren.

Holmboe, Tage (1961). Højesteret og strafferetten. I Povl Bagge, Jep Lausen Frost og Bernt Hjejle (red.), Højesteret 1661-1961, 1. bind. København: G E C Gads Forlag, s. 63-202.

Nielsen, Beth Grothe (1999). Letfærdige qvindfolk - om Gisle Nielsdatter og andre barnemodersker. Aarhus: Aarhus Universitetsforlag.

Rosen, Wilhelm von (1993). Månes kulør. Studier i dansk Bøssehistorie 1628-1912. Bind 1. København: Rhodos.

Schous Forordninger, udgivet 1745-1840.

Straffelovrådets betcenkning $2012 \mathrm{nr} .1534$ om seksualforbrydelser.

Tamm, Ditlev, Bjørn, Claus og Westrup, Morten (2006). Til det almindelige bedste... Generalprokurør Christian Colbiørnsens lovbetænkninger 1789-1802. København: Jurist- og Økonomforbundets Forlag.

Tamm, Ditlev og Kjær, Morten (2013). Henrik Stampe - Enevældens menneskelige ansigt. København: Jurist- og Økonomforbundets Forlag.

Udkast til Straffelovbog for Danmark med tilhørende Motiver. Udarbeidet af den allerhøieste Kommissorium af 22de Februar 1859 dertil anordnede Kommission, J.H. Schultz 1864 [Udkast til Straffelovbog].

Viskum, Bjarke (2018). Politisk filosofi og argumentationsteori for jurister. København: Hans Reitzels Forlag. 